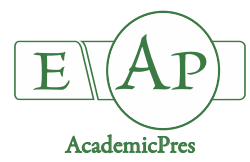

\title{
Effects of Vanadium and Nickel on Morphological Characteristics and on Vanadium and Nickel Uptake by Shoots of Mojito (Mentha $\times$ villosa) and Lavender (Lavandula anqustifolia)
}

\author{
Pantelis E. BAROUCHAS ${ }^{1}$, Anastasia AKOUMIANAKI-IOANNIDOU ${ }^{2}$, \\ Aglaia LIOPA-TSAKALIDI ${ }^{1}$, Nicholas K. MOUSTAKAS ${ }^{3 *}$ \\ ${ }^{1}$ Technological Educational Institute of Western Greece, M. Alexandrou 1, Koukouli, 26334 Patra, \\ Greece; pbar@teiwest.gr; aliopa@teiwest.gr \\ ${ }^{2}$ Agricultural University of Athens, School of Agriculture Production, Infrastructure and Environment, Department of Crop Science, Laboratory \\ of Floriculture and Landscape Architecture, Iera Odos 75, 11855 Athens, Greece; akouman@aua.gr \\ ${ }^{3}$ Agricultural University of Athens, School of Agriculture Production, Infrastructure and Environment, Department of Natural Resources \\ Management and Agricultural Engineering, Laboratory of Soil Science and Agricultural Chemistry, Iera Odos 75, 118 55, Athens, \\ Greece;nmoustakas@aua.gr (*orrespondingauthor)
}

\begin{abstract}
Vanadium and Nickel may enter the human food chain through medicinal and culinary plants which in great doses are toxic to human, so it is important to determine their potential toxicity and health risk. Therefore, the objective of this work was to study the effects of Vanadium and Nickel on morphological characteristics and on Vanadium and Nickel uptake by shoots of mojito (Mentha $\times$ vilosa) and lavender (Lavandula anqustifolia). A completely randomized block design with five Vanadium treatments $\left(0,5,10,20,40 \mathrm{mg} \mathrm{V} \mathrm{L}^{-1}\right)$ and five replications per treatment and another one with five Nickel treatments $\left(0,5,10,20\right.$ and $\left.40 \mathrm{mg} \mathrm{Ni} \mathrm{L}^{-1}\right)$ and five replications per treatment for mojito and lavender were conducted in pots. No visible toxic or inhibitory symptoms were observed on the plants due to the increasing amounts of Vanadium or Nickel. Shoot dry matter and root dry matter of mojito and lavender decreased with increasing Vanadium rates. Vanadium uptake by shoots of mojito and lavender increased linearly with increasing Vanadium rates. Nickel uptake by shoots of lavender increased linearly with increasing rates of Nickel. Mojito is a Nickel accumulator.
\end{abstract}

Keywords: culinary herbs; heavy metals accumulators; medicinal herbs

Abbreviations: SDM - shoot dry matter; STN - stem number; STL - stem length; RDM - root dry matter; RL - root length

\section{Introduction}

Vanadium (V) is a transition metal and is widely distributed in the earth's crust with an average concentration of $110 \mathrm{mg} \mathrm{kg}^{-1}$ (Peterson and Girling, 1981). The concentration of vanadium in soil depends upon the parent material and on the industrial pollution (WHO, 1987). The fate of vanadium in soils depends on iron and aluminumoxides and hydroxides that determine vanadium mobility in soils and waters (Naeem et al., 2007). The evidence that $\mathrm{V}$ is essential for the growth of higher plants is, however, not yet conclusively demonstrated. It does not meet the criteria of essentiality which set by Arnon and Wessel (1953). Toxicity of vanadium to plants has mainly been studied in nutrient solutions and starts from between
$1 \mathrm{mg} \mathrm{V} \mathrm{L}{ }^{-1}$ and $5 \mathrm{mg} \mathrm{V} \mathrm{L}^{-1}$ for the most sensitive species (Kaplan et al., 1990). Vanadium is toxic to humans at high $\mathrm{V}$ concentrations and can cause irritation of the respiratory tract, although it has not been possible to determine the level of exposure that provokes such effects (Costigan et al., 2001). Several medicinal plants manifest a tendency to take up higher amounts of heavy metals than other plants. Mojito Mint (Mentha $x$ villosa) is a species of perennial herbs in the family Lamiaceae. It is commonly grown for its edible qualities. Often used as a domestic herbal remedy, being valued especially for its antiseptic properties and its beneficial effect on the digestion (Martins et al., 2007). Lavender (Lavandula anqustifolia) is a flowering plant in the family Lamiaceae, native to the Mediterranean areas. It is a strongly aromatic shrub growing as high as 1 to $2 \mathrm{~m}$ tall. 
488

The leaves are evergreen and the flowers are pinkish-L, produced on spikes $2-8 \mathrm{~cm}$ long at the top of slender (Erland and Mahmoud, 2016).

Nickel $(\mathrm{Ni})$ occurs abundantly in igneous rocks as a free metal or as a complex with iron. It stands at twenty-second position amongst most abundant elements in the earth crust (Sunderman and Oskarsson, 1991). Additionally, anthropogenic activities release $\mathrm{Ni}$ into the soil through various sources such as smelting, burning of fossil fuel, vehicle emissions, disposal of house hold, municipal and industrial wastes, metal mining, fertilizer application, and organic manures (Alloway, 2013). During the last decades, $\mathrm{Ni}$ has become a serious concern as its concentration has reached up to $26,000 \mathrm{mg} \mathrm{kg}^{-1}$ in polluted soils (Conelli and Renella, 2013) and $0.2 \mathrm{mg} \mathrm{L}^{-1}$ in polluted surface waters (Zwolsman and Van Bokhoven, 2007). $\mathrm{Ni}$ in adequate quantities has vital roles in a wide range of physiological processes, starting from seed germination to the productivity. Moreover, plants cannot complete their life cycle without adequate supply of this metal. Therefore, $\mathrm{Ni}$ belongs to the list of essential micronutrients. Besides this, at elevated level it alters all the metabolic activities of the plant such as water relation and mineral nutrition, causes enzyme inhibition, disrupts stomatal functioning, photosynthetic electron transport and degrades chlorophyll molecules, consequently minimizes the photosynthetic rate, and biological yield of plants (Yusuf et al., 2011). Excessive Ni levels in the soil can result in toxicity to plants (Amari et al., 2014). The common indicators of $\mathrm{Ni}$ phytotoxicity to plants include inhibition of germination, leaf spotting, chlorosis, abnormal flower shape, reduced growth of roots and shoots, deformation of plant parts, poor branching, and decreased yield. The toxicity of $\mathrm{Ni}$ in plants has become a world-wide problem threatening sustainable agriculture as well. The critical toxicity level of $\mathrm{Ni}$ is more than $10 \mathrm{mg} \mathrm{kg}^{-1}$ DW in sensitive species (Kozlow, 2005), $50 \mathrm{mg} \mathrm{kg}^{-1} \mathrm{DW}$ in moderately tolerant species (Bollard, 1983; Asher, 1991) and $1,000 \mathrm{mg} \mathrm{kg}^{-1} \mathrm{DM}$ in $\mathrm{Ni}$ hyper accumulator plants such as Alyssum and Thalspi species (Kupper et al., 2001; Pollard et al., 2002). The impact of Ni toxicity on the physiology of plants depends on the type of plant species, growth stage, cultivation conditions, Ni concentration and exposure time (Kabata-Pendias, 2011) in the soil. In the absence of $\mathrm{Ni}$, plants develop specific deficiency symptoms, like leaf tip burn due to excessive accumulation of urea whereas its excess has been reported to cause leaf necrosis and chlorosis of plants (Marschner, 2002; Seregin and Kozhevnikova, 2006). It is evident from available literature that $\mathrm{Ni}$ affects plant growth at cellular, organ and the organism level (Bishnoi et al., 1993). Nickel has been tested for a small number of plants, thus the information available on this topic should be valuable. More information on Ni levels in plant tissues that are consumed by mammals, and its effect on plant growth, is required. Several medicinal and culinary plants manifest a tendency to take up higher amounts of heavy metals than other useful plants. Mojito (Mentha $x$ villosa) and Lavender (Lavandula anqustifolia) are medicinal and culinary herbs and up till now we have little information on the response to increasing additions of $\mathrm{V}$ or $\mathrm{Ni}$ in the soil. Consequently, the objectives of this research were to examine the effect of $\mathrm{V}$ and $\mathrm{Ni}$ on morphological characteristics (stem number (STN), stem length (STL), root length (RL)), shoot (SDM) and root dry matter
(RDM)), and on V and Ni uptake by shoots of mojito and lavender.

\section{Materials and Methods}

\section{Experimental conduction and desion}

A completely randomized block design with five $\mathrm{V}$ treatments $\left(0,5,10,20,40 \mathrm{mg} \mathrm{V} \mathrm{L}^{-1}\right)$ and five replications per treatment for mojito and lavender, and another one with five Ni treatments $\left(0,5,10,20\right.$ and $\left.40 \mathrm{mg} \mathrm{Ni} \mathrm{L}^{-1}\right)$ and five replications per treatment for mojito and lavender were conducted in pot experiments ( 50 pots for mojito and 50 pots for lavender $=100$ pots totally). The plants grown on pots filled with peat and perlite medium $(1: 1 \mathrm{v} / \mathrm{v})$ with $\mathrm{pH}$ 6.9. Vanadium was applied as $\mathrm{NH}_{4} \mathrm{VO}_{3}$ and $\mathrm{Ni}$ as $\mathrm{NiCl}_{2} 6 \mathrm{H}_{2} \mathrm{O}$. Vanadium and $\mathrm{Ni}$ were added two times per week with $25 \mathrm{ml}$ of each treatment per pot for five weeks (total $250 \mathrm{ml}$ per pot of each treatment for the whole cultivation period, i.e. $14.3 \mathrm{mg} \mathrm{V}, 28.7 \mathrm{mg} \mathrm{V}, 57.4 \mathrm{mg} \mathrm{V}$ and $114.8 \mathrm{mg} \mathrm{V}$ for $5 \mathrm{mg} \mathrm{V} \mathrm{L}^{-1}, 10 \mathrm{mg} \mathrm{V} \mathrm{L}^{-1}, 20 \mathrm{mg} \mathrm{V} \mathrm{L}^{-1}$ and 40 $\mathrm{mg} \mathrm{V} \mathrm{L}{ }^{-1}$, respectively and $25.3 \mathrm{mg} \mathrm{Ni}, 50.6 \mathrm{mg} \mathrm{Ni}, 101.2$ $\mathrm{mg} \mathrm{Ni}$ and $202.5 \mathrm{mg} \mathrm{Ni}$ for $5 \mathrm{mg} \mathrm{Ni} \mathrm{L}^{-1}, 10 \mathrm{mg} \mathrm{Ni} \mathrm{L}^{-1}, 20$ $\mathrm{mg} \mathrm{Ni} \mathrm{L}{ }^{-1}$ and $40 \mathrm{mg} \mathrm{Ni} \mathrm{L}^{-1}$, respectively. Fertilization of the pots was performed approximately every two weeks, using a commercial fertilizer (Nutrileaf-60) with $2 \mathrm{mg} \mathrm{N}, 2 \mathrm{mg}$ $\mathrm{P}_{2} \mathrm{O}_{5}$, and $2 \mathrm{mg} \mathrm{K}_{2} \mathrm{O}$ for each pot (the content of $\mathrm{V}$ and $\mathrm{Ni}$ in the fertilizer was negligible).

\section{Plant analysis}

At the end of the experiment, leaves, stems and roots were harvested. STN per pot as well as SL, RL per plant were measured. Then leaves stems and roots were ovendried at $50{ }^{\circ} \mathrm{C}$ to constant weight, weighted and then grounded in a stainless steel Wiley mill and passed through a $150 \mu \mathrm{m}$ plastic sieve, $0.5 \mathrm{~g}$ of plant parts smaller than 150 $\mu \mathrm{m}$ in diameter from each pot were placed in beakers and ashed at $450^{\circ} \mathrm{C}$. The residue was dissolved in $5 \mathrm{ml}$ of $6 \mathrm{~N}$ $\mathrm{HCl}$. The clear solutions were analyzed by ICP-OES (Thermo Scientific iCAP 6000) for $\mathrm{V}$ and $\mathrm{Ni}$.

\section{Soil analysis}

At the end of each experiment samples of air-dried soil from each plant species and each pot were collected, passed through a $500 \mu \mathrm{m}$ plastic sieve and analyzed for extractable $\mathrm{V}$ and $\mathrm{Ni}$ using the diethylene triamine penta acetic acidtriethanol amine (DTPA-TEA) method following procedure of Lindsay and Norvell (1978): 0.005M DTPA, $0.01 \mathrm{M} \mathrm{CaCl}_{2}$ and $0.1 \mathrm{M} \mathrm{TEA}$, was adjusted to $\mathrm{pH} 7.3$ with $1 \mathrm{~N} \mathrm{HCl}$. Ten grams of soil and $20 \mathrm{ml}$ DTPA-TEA extracting solution were placed in polyethylene flasks covered with a plastic stopper and shaken by horizontalcircular movements at 240 oscillations per minute for 2 hours. The suspensions were filtered by gravity through Whatman no. 42 filter paper. The filtrates were analyzed for $\mathrm{V}$ and Ni by ICP-OES (Thermo Scientific iCAP 6000).

\section{Statistical analysis}

ANOVA was used for statistical analysis using STATISTICA (2008). Where a significant difference was found, the Duncan's Multiple Range Test at the 5\% level of probability was used to compare individual treatment means. 


\section{Results and Discussion}

\section{Mojito and lavender as affected by Vanadium}

During the experiment no toxic symptoms or inhibitory effects on mojito and lavender due to increasing application rates of $\mathrm{V}$ were observed. The same results reported by Akoumianaki-Ioannidou et al. (2015) for pennyroyal and by Akoumianaki-Ioannidou et al. (2016) for sweet basil using the same amounts of added V. SDM and RDM of mojito decreased at rates above 10 and $5 \mathrm{mg} \mathrm{V} \mathrm{L} \mathrm{L}^{-1}$, respectively (Table 1). SDM and RDM of lavender decreased significantly at rates above 20 and $5 \mathrm{mg} \mathrm{V} \mathrm{L}^{-1}$, respectively (Table 2 ). STN and $\mathrm{RL}$ in mojito decreased at rates above 20 and $10 \mathrm{mg} \mathrm{V} \mathrm{L}^{-1}$, respectively (Table 1). STN, STL and RL were not affected by increasing rates of $\mathrm{V}$ in lavender (Table 2). Vanadium uptake (Shoot Dry Mater x $\mathrm{V}$ concentration in shoots) by shoots of mojito and lavender increased linearly with increasing $\mathrm{V}$ rates (Figs. 1 and 2 ). Singh (1971) detected an increase in dry matter when corn was subjected to doses of $\mathrm{V}$ from 0.05 to $0.25 \mathrm{mg} \mathrm{L}^{-1}$. Basiouny (1984) found that the dry matter of tomato plants increased when they were exposed to $0.2 \mathrm{mg} \mathrm{V} \mathrm{L} \mathrm{L}^{-1}$. Vachirapatame et al. (2005) found that the growth of Chinese green mustard and tomato plants was retarded by nutrient solutions containing at least $40 \mathrm{mg} \mathrm{V} \mathrm{L}^{-1}$. Akoumianaki-Ioannidou et al. (2015) for pennyroyal treated with the same $\mathrm{V}$ treatments as our own experiment reported that LDM and RDM increased with doses above 5 $\mathrm{mg} \mathrm{V} \mathrm{L}{ }^{-1}$. Also Akoumianaki-Ioannidou et al. (2016) for sweet basil treated with the same $V$ treatments as our own experiment, reported that LDM was not affected by $\mathrm{V}$ addition, in contrast RDM increased linearly with increasing $\mathrm{V}$ additions.

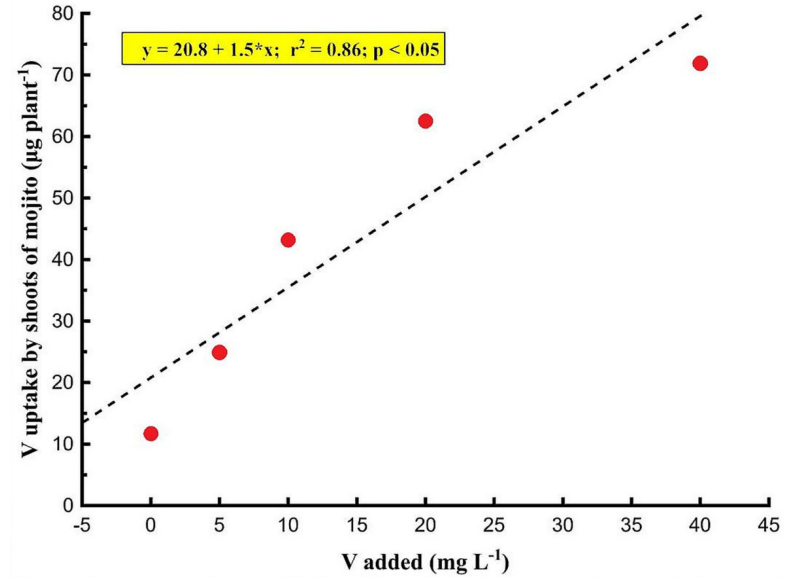

Fig. 1. Vanadium uptake by shoots of mojito as affected by Vanadium

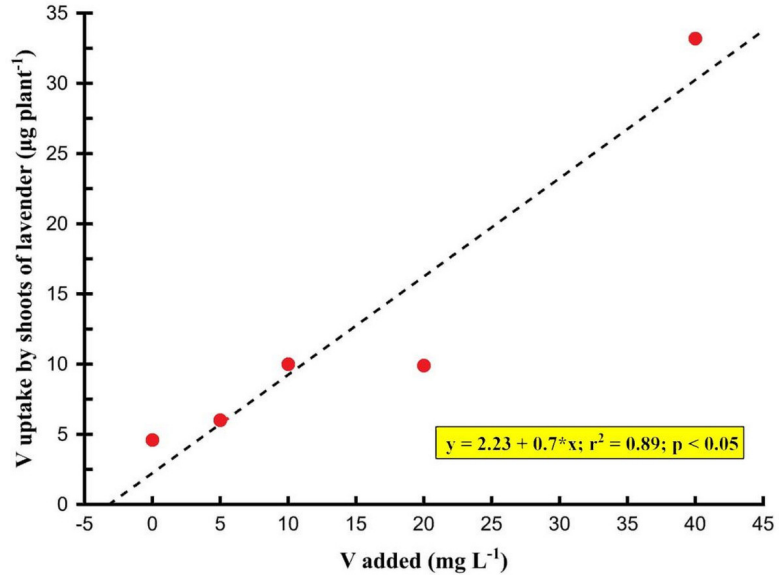

Fig. 2. Vanadium uptake by shoots of lavender as affected by Vanadium

Table 1. Effects of V treatments on morphological characteristics (shoot dry matter (SDM), stem number (STN), stem length (STL), root length $(\mathrm{RL})$, and root dry matter $(\mathrm{RDM}))$ of mojito, and on $\mathrm{V}$ concentration in soil

\begin{tabular}{|c|c|c|c|c|c|c|}
\hline $\mathrm{V}$ added $\left(\mathrm{mg} \mathrm{L}^{-1}\right)$ & $\operatorname{SDM}(\mathrm{g})$ & STN & $\mathrm{STL}(\mathrm{cm})$ & $\mathrm{RL}(\mathrm{cm})$ & $\operatorname{RDM}(\mathrm{g})$ & $\mathrm{V}$ (soil) $\left(\mu \mathrm{gg}^{-1}\right.$ soil $)$ \\
\hline 0 & $20.4 \mathrm{a}$ & $29.2 \mathrm{a}$ & 29.6 & $21.8 \mathrm{~b}$ & $70.3 b$ & 4.9 \\
\hline 5 & $18.6 \mathrm{a}$ & $28.6 \mathrm{a}$ & 29.0 & $19.6 \mathrm{ab}$ & $56.5 \mathrm{~b}$ & 4.8 \\
\hline 10 & $17.6 \mathrm{ab}$ & $25.0 \mathrm{a}$ & 27.4 & $20.0 \mathrm{ab}$ & $32.5 \mathrm{a}$ & 5.3 \\
\hline 20 & $14.0 \mathrm{~b}$ & $23.8 \mathrm{a}$ & 27.4 & $13.8 \mathrm{a}$ & $33.9 \mathrm{a}$ & 5.1 \\
\hline 40 & $13.9 \mathrm{~b}$ & $17.8 \mathrm{~b}$ & 24.6 & $14.2 \mathrm{a}$ & $25.9 a$ & 4.9 \\
\hline $\mathrm{F}=$ & 3.39 & & & 2.8 & 3.38 & \\
\hline
\end{tabular}
no significance by Duncan's test at $\mathrm{p} \leq 0.05$

Table 2. Effects of V treatments on morphological characteristics (shoot dry matter (SDM), stem number (STN), stem length (STL), root length $(\mathrm{RL})$, and root dry matter $(\mathrm{RDM}))$ of lavender, and on $\mathrm{V}$ concentration in soil

\begin{tabular}{|c|c|c|c|c|c|c|}
\hline $\mathrm{V}$ added $\left(\mathrm{mg} \mathrm{L}^{-1}\right)$ & $\operatorname{SDM}(\mathrm{g})$ & STN & $\operatorname{STL}(\mathrm{cm})$ & $\mathrm{RL}(\mathrm{cm})$ & RDM (g) & $\mathrm{V}$ (soil) ( $\mu \mathrm{gg}^{-1}$ soil) \\
\hline 0 & $11.8 \mathrm{~b}$ & 39.0 & 16.4 & 13.1 & $9.6 \mathrm{~b}$ & 8.6 \\
\hline 5 & $10.6 \mathrm{ab}$ & 35.0 & 15.6 & 11.9 & $7.5 \mathrm{ab}$ & 8.9 \\
\hline 10 & $10.4 \mathrm{ab}$ & 32.6 & 14.6 & 10.3 & $6.6 \mathrm{~b}$ & 8.8 \\
\hline 20 & $10.5 \mathrm{ab}$ & 31.5 & 13.0 & 11.9 & $5.4 \mathrm{~b}$ & 8.8 \\
\hline 40 & $8.7 \mathrm{~b}$ & 30.1 & 14.8 & 7.3 & $5.4 \mathrm{~b}$ & $8.7 \mathrm{a}$ \\
\hline $\mathrm{F}=$ & 2.61 & & & & 2.6 & \\
\hline
\end{tabular}


490

Mojito and lavender as affected by Nickel

No visible toxic or inhibitory symptoms were observed on the plants due to the increasing rates of $\mathrm{Ni}$ during the experiment. SDM, STN, STL, RDM, and RL were not affected by $\mathrm{Ni}$ in the studied plants (Tables 3, 4). Ni uptake by lavender increased linearly with increasing rates of $\mathrm{Ni}$ (Fig. 3). Nickel uptake by mojito did not affected by $\mathrm{Ni}$ and is greater than the added $\mathrm{Ni}$ and approximately twenty times greater than that extracted with DTPA - TEA Ni from soil (Table 3). These results in combination with the fact that no toxic or inhibitory symptoms were observed in plants of mojito lead us to conclude that mojito is possibly a $\mathrm{Ni}$ accumulator, but more research is needed on this. Other researchers reported that exposure to $0.085-0.255 \mathrm{mM}$ (5$15 \mathrm{ppm}) \mathrm{Ni}$, for a week, developed chlorosis and necrosis along the veins in newly developed leaves of water spinach (Sun and Wu, 1998). Nickel at a concentration of $0.5 \mathrm{mM}$ produced dark brown necrotic spots along the leaf margins and decreased water potential and transpiration rate, resulting in the wilting of outer leaves (Panday and Sharma, 2002). Similarly, barley grown in $0.1 \mathrm{mM} \mathrm{Ni}$ for 14 days had foliar chlorosis and necrosis (Rahman et al., 2005). Bashmakov et al. (2006) also observed a significant decrease in leaf area even at lower doses $(50$ and $0.1 \mathrm{mM})$ of $\mathrm{Ni}$.

Vanadium and Ni extracted by DTPA-TEA from soil were not affected by $\mathrm{V}$ and $\mathrm{Ni}$ (Tables 1, 2,3,4) and did not correlated with $\mathrm{V}$ or $\mathrm{Ni}$ uptake by shoots in the studied plants indicating that this extractant should not be useful to predict $\mathrm{V}$ and Ni uptake by shoots of mojito or lavender. Moustakas et al. (2001), Moustakas et al. (2011), and Akoumianakis et al. (2008) reported that this extractant should be used for predicting Cd concentrations in lettuce, radish, cucumber, endive, rocket and pot-grown marigold plants.

Table 3. Effects of Ni treatments on morphological characteristics (shoot dry matter (SDM), stem number (STN), stem length (STL), root length $(\mathrm{RL})$, and root dry matter $(\mathrm{RDM}))$ of mojito, and on Ni concentration in soil

\begin{tabular}{ccccccc}
\hline $\begin{array}{c}\text { Ni added } \\
\left(\mathrm{mg} \mathrm{L}^{-1}\right)\end{array}$ & SDM $(\mathrm{g})$ & STN & $\begin{array}{l}\text { STL } \\
(\mathrm{cm})\end{array}$ & RL $(\mathrm{cm})$ & RDM $(\mathrm{g})$ & Ni uptake $\left(\mu \mathrm{g} \mathrm{plant}{ }^{-1}\right)$ \\
\hline 0 & 24.5 & 23.9 & 30.4 & 16.2 & 38.7 & 169.2 \\
5 & 24.9 & 27.2 & 25.2 & 14.6 & 35.4 & 213.0 \\
10 & 23.8 & 23.6 & 22.0 & 13.4 & 38.6 & 211.9 \\
20 & 21.1 & 25.2 & 23.2 & 14.2 & 43.3 & 236.1 \\
40 & 21.6 & 20.8 & 20.4 & 12.8 & 52.4 & 8.9 \\
\hline
\end{tabular}

Table 4. Effects of Ni treatments on morphological characteristics (shoot dry matter (SDM), stem number (STN), stem length (STL), root length $(\mathrm{RL})$, and root dry matter $(\mathrm{RDM}))$ of lavender, and on $\mathrm{Ni}$ concentration in soil

\begin{tabular}{|c|c|c|c|c|c|c|}
\hline $\mathrm{Ni}$ added $\left(\mathrm{mg} \mathrm{L}^{-1}\right)$ & $\mathrm{SDM}(\mathrm{g})$ & STN & $\mathrm{STL}(\mathrm{cm})$ & $\mathrm{RL}(\mathrm{cm})$ & $\mathrm{RDM}(\mathrm{g})$ & $\mathrm{Ni}$ (soil) $\left(\mu \mathrm{gg}^{-1}\right.$ soil $)$ \\
\hline 0 & 11.2 & 14.8 & 14.8 & 9.3 & 9.3 & 9.7 \\
\hline 5 & 10.8 & 13.6 & 13.6 & 9.7 & 9.7 & 9.8 \\
\hline 10 & 10.5 & 17.0 & 17.0 & 9.7 & 9.7 & 9.9 \\
\hline 20 & 9.4 & 13.2 & 13.2 & 11.5 & 11.5 & 9.6 \\
\hline 40 & 9.4 & 16.4 & 16.4 & 12.9 & 12.9 & 9.4 \\
\hline
\end{tabular}

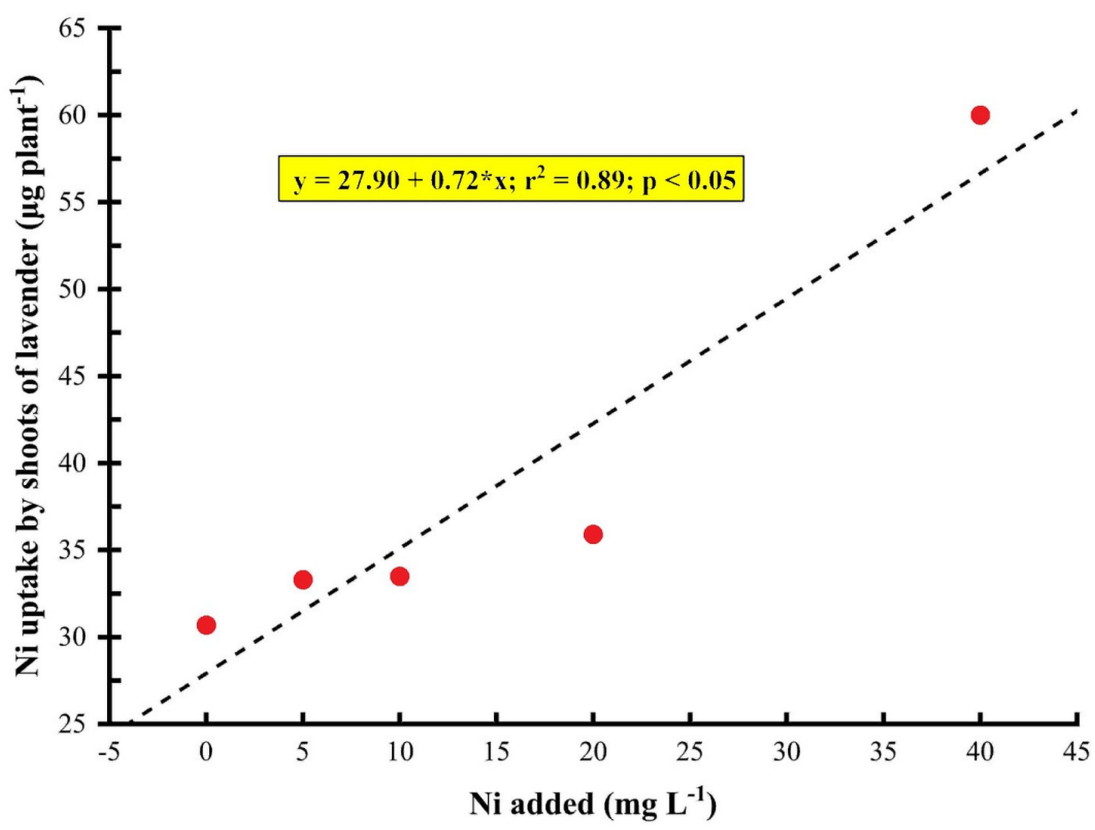

Fig. 3. Nickel uptake by shoots of lavender as affected by Nickel 


\section{Conclusions}

Mojito and lavender did not reveal toxic or inhibitory symptoms growth in soils contains up to $40 \mathrm{mg} \mathrm{L}^{-1} \mathrm{~V}$ or $\mathrm{Ni}$. Vanadium uptake by shoots of mojito and lavender increased linearly with increasing rates of $\mathrm{V}$. Nickel uptake by shoots of lavender increased linearly with increasing rates of Ni. Morphological characteristics of Mojito and lavender were not affected by increasing rates of $\mathrm{V}$ or Ni. Mojito is a $\mathrm{Ni}$ accumulator. DTPA-TEA should not be used as extractant in order to predict $\mathrm{V}$ and $\mathrm{Ni}$ uptake by the above ground plant parts (shoots) of mojito and lavender.

\section{References}

Akoumianaki-Ioannidou A, Barouchas PE, Ilia E, Kyramariou A, Moustakas NK (2016). Effect of vanadium on dry matter and nutrient concentration in sweet basil (Ocimum basilicum L.). Australian Journal ofCropScience 10(2):199-206.

Akoumianaki-Ioannidou A, Barouchas PE, Kyramariou A, Ilia E, Moustakas NK (2015). Effect of vanadium on dry matter and nutrient concentration in pennyroyal (Mentha pulegium L.). Bulletin UASVM Horticulture 72(2):295-298.

Akoumianakis KA, Passam HC, Barouchas PE, Moustakas NK (2008). Effect of cadmium on yield and cadmium concentration in the edible tissue of endive (Cichorium endivia L.) and rocket (Eruca sativa Mill.). Journal of Food Agriculture and Environment 6:201-209.

Alloway BJ (2013). Heavy Metals in Soils. Springer (3nded), Dordrecht.

Amari T, Ghnaya T, Debez A, Taamali M, Youssef NB, Lucchini G, Sacchib GA, Abdelly C (2014). Comparative Ni tolerance and accumulation potentials between Mesembryanthemum crystallinum (halophyte) and Brassica juncea: Metal accumulation, nutrient status and photosynthetic activity. Journal Plant Physiology 171:16341644.

Arnon DI, Wessel G(1953). Vanadium as essential element for green plants. Nature 172:1039-1040.

Asher CJ (1991). Beneficial elements, functional nutrients, and possible new essential elements. In: Mortvedt JJ, Cox FR, Shuman LM, Welch RM (Eds). Micronutrients in Agriculture. Soil Science Society of America, Madison, Wisconsin pp 703-723.

Bashmakov DI, Lukatkin AS, Prasad MNV (2006). Temperate weeds in Russia: sentinels for monitoring trace element pollution and possible application in phytoremediation. In: Trace elements application of quantitative fluorescence and absorption-edge computed microtomography to image metal compartmentalization in Alyssum murale. Environmental Science Technology 39:2210-2218.

Basiouny FM (1984). Distribution of vanadium and its influence on chlorophyll formation and iron metabolism in tomato plants. Journal Plant Nutrition 7:1059-1073.

Bishnoi NR, Sheoran IS, Singh R (1993). Influence of cadmium and nickel on photosynthesis and water relations in wheat leaves of differential insertion levels. Photosynthetica 28:473-479.

Bollard EG (1983). Involvement of unusual elements in plant growth and nutrition. In: Lauchli A, Bieleski RL (Eds). Encyclopedia of Plant Physiology.Springer pp 695-744.
Costigan M, Cary R, Dobson S (2001). Vanadium pentoxide and other inorganic vanadium compounds. Concise International Chemical Assessment Document 29. World Health Organization pp 1-69.

Erland LA, Mahmoud SS (2016). Lavender (Lavandula angustifolia) Oils. In: Preedy VR (Ed). Essential Oils in Food Preservation, Flavor and Safety. Academic Press pp 501-508.

Gonnelli C, Renella G (2013). Chromium and Nickel. In: Alloway BJ (Ed). Heavy Metals in Soils. Springer, Dordrecht pp 313-333.

Kabata-Pendias A (2011). Trace elements in soils and plants. CRC Press ( $4^{\text {th }}$ ed), Taylor \& Francis Group, Boca Raton, FL.

Kaplan DI, Adriano DC, Carlson CL, Sajwan KS (1990). Vanadium toxicity and accumulation by beans. Water Air Soil Pollution 49:81-91.

Kozlow MV (2005). Pollution resistance of mountain birch, Betulapubescens subsp. czerepanovii, near the copper-nickel smelter: natural selection or phenotypic acclimation? Chemosphere 59:189-197.

Kupper H, Lombi E, Zhao FJ, Wieshammer G, McGrath SP (2001). Cellular compartmentation of nickel in the hyperaccumulators Alyssum lesbiacum, Alyssum bertolonii and Thlaspi goesingense. Journal Experimental Botany 52:2291-3000.

Linsday WL, Norvell WA (1978). Development of a DTPA soil test for zinc, iron, manganese and copper. Soil Science Society of America Journal 31:421-428.

Marschner H (2002). Mineral nutrition of higher plants. Academic Press (3nd ed), London.

Martins AP, Craveiro AA, Machado M, Raffin F, Moura T, Novák Cs, Éhen Z (2007). Preparation and characterization of Mentha $\times$ villosa Hudson oil- $\beta$-cyclodextrin complex. Journal of Thermal Analysis and Calorimetry 88(2):363-371.

Moustakas NK, Akoumianaki-Ioannidou A, Barouchas P. (2011). The effects of cadmium and zinc interactions on the concentration of cadmium and zinc in pot marigold (Calendula officinalis L.). Australian Journal ofCrop Science 5:277-282.

Moustakas NK, Akoumianakis KA, Passam HC (2001). Cadmium accumulation and its effect on the yield of Lettuce, Radish and Cucumber. Communication in Soil Science and Plant Analysis 32:1793-1802.

Naeem A, Westerhoff P, Mustafa S (2007). Vanadium removal by metal (hydr)oxide adsorbents. Water Research 41:1596-1602.

Panday N, Sharma CP (2002). Effect of heavy metals $\mathrm{Co}^{2+}, \mathrm{Ni}^{2+}$, and $\mathrm{Cd}^{2+}$ on growth and metabolism of cabbage. Plant Science 163:753-758.

Peterson PJ, Girling CA (1981). Other Trace Metals. In: Lepp NW (Ed). Effect of Heavy Metal Pollution on Plants. Academic Science Publishers, London pp 210-277.

Pollard AJ, Powell KD, Harper HA, Smith JAC (2002). The genetic basis of metal hyperaccumulation in plants. Critical Review Plant Science 21:539-566.

Rahman H, Sabreen S, Alam S, Kawai S (2005). Effects of nickel on growth and composition of metal micronutrients in barley plants grown in nutrient solution. Journal Plant Nutrition 28:393-404.

Seregin IV, Kozhevnikova AD (2006). Physiological role of nickel and its toxic effects on higher plants. Russian Journal Plant Physiology 53:257277. 
492

Singh BB (1971). Effect of vanadium on the growth, yield and chemical composition of maize (Zea mays L.). Plant Soil 34:209-212.

STATISTICA(1998).StatSoft, Inc. Tulsa, OK, USA.

Sun EJ, Wu FY (1998). Along-vein necrosis as indicator symptom on water spinach caused by nickel in water culture. Botanical Bulletin Academia Sinica 39:255-259.

Sunderman FW, Oskarsson A (1991). Nickel. In: Merian E, Weinheim N (Eds). Metals and their compounds in the environment. Occurrence, analysis and biological relevance. VCH Publishers, New York pp 11011126.

Vachirapatama N, Jirakiattikul Y, Dicinoski G, Townsend AT, Haddad PR (2005). On-line preconcentration and sample clean-up system of vanadium as 4(2-pyridylazo) resorcinol (PAR) and hydrogen peroxide ternary complex in plant tissues by ion interaction HPLC. Analytica Chimica Acta 543:70-76.
WHO (1987). Air quality guidelines for Europe. Copenhagen. World Health Organization. Regional Office for Europe.

Yusuf M, Fariduddin Q, Hayat S, Ahmad A (2011). Nickel: An Overview of Uptake, Essentiality and Toxicity in Plants. Bulletin Environmental Contamination Toxicology 86:9-17.

Zwolsman JJG, Van Bokhoven AJ (2007). Impact of summer droughts on water quality of the Rhine River-a preview of climate change. Water Science Technology 56:45-55. 